

\title{
New Sensitive Spectrophotometric Methods for the Determination of Raloxifene Hydrochloride in Pharmaceuticals Using Bromate-Bromide, Methyl Orange and Indigo Carmine
}

\author{
K BASAVAIAH* and U. R. ANIL KUMAR \\ Department of Chemistry \\ University of Mysore \\ Manasagangotri, \\ Mysore- 570 006, India
}

Received 6 June 2006; Accepted 31 July 2006.

\begin{abstract}
Two new sensitive spectrophotometric methods are proposed for the determination of raloxifene hydrochloride (RLX) using bromate-bromide mixture and two dyes, methyl orange and indigocarmine, as reagents. The methods entail the addition of a known excess of bromate-bromide mixture to RLX in hydrochloric acid medium followed by determination of residual bromine by reacting with a fixed amount of either methyl orange and measuring the absorbance at $520 \mathrm{~nm}$ (Method A) or indigo carmine and measuring the absorbance at $610 \mathrm{~nm}$ (Method B). In both methods, the amount of bromine reacted corresponds to the amount of RLX. The absorbance is found to increase linearly with concentration of RLX. Under the optimum conditions, RLX could be assayed in the concentration range $0.1-2.0$ and $0.5-6.0 \mu \mathrm{g} \mathrm{mL}^{-1}$ by method $\mathrm{A}$ and method B, respectively. The apparent molar absorptivities are calculated to be $1.9 \times 10^{5}$ and $4.5 \times 10^{4} \mathrm{~L} \mathrm{~mol}^{-1} \mathrm{~cm}^{-1}$ for method $\mathrm{A}$ and method $\mathrm{B}$, respectively, and the corresponding Sandell sensitivity values are 0.003 and $0.011 \mu \mathrm{g} \mathrm{cm}^{-2}$. The limits of detection and quantification are also reported for both methods. Intra-day and inter-day precision and accuracy of the developed methods were evaluated as per the current ICH guidelines. The methods were successfully applied to the assay of RLX in its tablet formulation and the results were compared with those of a reference method by calculating the Student's t-value and F-value. No interference was observed from common tablet adjuvants. The accuracy and reliability of the methods were further ascertained by recovery experiments via standard-addition procedure.
\end{abstract}

Keywords: Raloxifene hydrochloride, assay, spectrophotometry, bomate-bromide, tablets 


\section{Introduction}

Raloxifene hydrochloride(RLX) is a selective estrogen receptor modulator that belongs to the benzothiophene class of compounds ${ }^{1}$ (Figure 1). The chemical designation is methanone, [6-hydroxy-2- (4-hydroxyphenyl) benzo[b]thien-3-yl]-[4-[2-(1-piperidinyl) ethoxy]phenyl]hydrochloride. RLX is used for the treatment and prevention of osteoporosis in postmenopausal women.

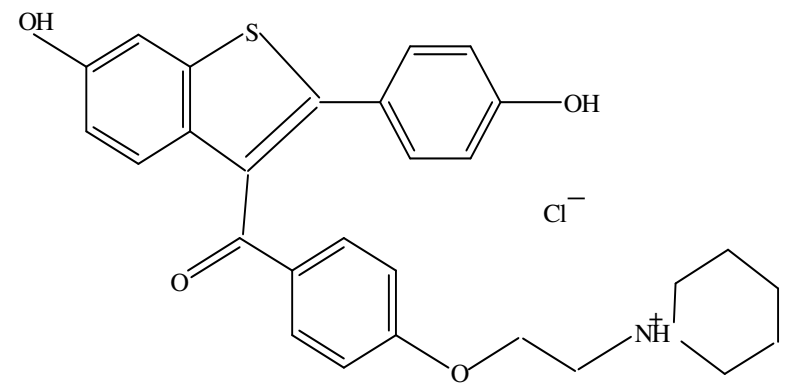

Figure 1. Structure of raloxifene hydrochloride

Literature on the methods for the determination of RLX in pharmaceuticals is scanty. High performance liquid chromatography (HPLC) has been used for the assay of RLX in bulk drug ${ }^{2}$ and in dosage forms ${ }^{3-5}$, but the methods are found to be far less sensitive. Chen et al. ${ }^{6}$ have recently proposed an UV-spectrophotometric method for determination of RLX in capsules. A quantitative assay method for RLX in pharmaceutical preparations by capillary electrophoresis ${ }^{7}$ has recently been reported by Perez-Ruiz et al. A some what sensitive method based on the measurement of the intensity of resonance Rayleigh scattering (RRS $)^{8}$ of the ion association complex of RLX with Evans Blue was developed by Fan et al. but, the method requires an expensive instrumental set up. Visible spectrophotometry, inspite of its simplicity, reasonable accuracy and precision, and speed, has not been widely applied for the assay of RLX. There is only one report on the visible spectrophotometric ${ }^{9}$ determination of RLX, and contains two procedures. One method is based on the measurement of bluish green chromogen formed when the drug is treated with ferricferricyanide reagent. The other involves the reduction of Fehling's reagent by RLX followed by measurement of blue-green species at $430 \mathrm{~nm}$.

The present investigation aims to develop sensitive and cost-effective methods for the determination of RLX in pure form and in dosage forms using spectrophotometric technique. The methods utilize bromate-bromide mixture and methyl orange and indigo carmine as reagents, which have successfully been used for the sensitive spectrophotometric determination of many bioactive substances ${ }^{10-18}$. The proposed methods have the advantages of speed and simplicity besides being accurate and precise, and can be adopted by the pharmaceutical laboratories for industrial quality control.

\section{Experimental}

\section{Apparatus}

A Systronics model 106 digital spectrophotometer with 1-cm matched quartz cells was used for all absorbance measurements. 


\section{Reagents and materials}

All chemicals used were of analytical reagent grade and distilled water was used to prepare all solutions. A stock solution equivalent to $1000 \mu \mathrm{g} \mathrm{mL}^{-1} \mathrm{KBrO}_{3}$ containing a large excess of $\mathrm{KBr}$ was prepared by dissolving accurately weighed $100 \mathrm{mg}$ of $\mathrm{KBrO}_{3}$ (Sarabhai M. chemicals, Baroda, India) and $1.0 \mathrm{~g}$ of $\mathrm{KBr}$ ( S.d. Fine Chem. Ltd., Mumbai, India) in water and diluting to $100 \mathrm{~mL}$ in a volumetric flask. The above solution was diluted appropriately with water to get 10 and $30 \mu \mathrm{g} \mathrm{mL}^{-1} \mathrm{KBrO}_{3}$ concentrations for use in method A and method $\mathrm{B}$, respectively. To prepare $50 \mu \mathrm{g} \mathrm{mL}^{-1}$ methyl orange for method A, first, a $500 \mu \mathrm{g} \mathrm{mL}^{-1}$ dye solution was prepared by dissolving accurately weighed $59 \mathrm{mg}$ of dye (S.d. Fine Chem., Mumbai, India, $85 \%$ dye content) in water and diluting to $100 \mathrm{~mL}$ in a calibrated flask, and filtered using glass wool. It was diluted to 10 -fold to obtain the required concentration. For method $\mathrm{B}$, a $1000 \mu \mathrm{g} \mathrm{mL} \mathrm{mL}^{-1}$ stock standard solution was first prepared by dissolving accurately weighed $112 \mathrm{mg}$ of dye (S.d. Fine Chem., Mumbai, India, 90\% dye content) in water and diluting to volume in a $100 \mathrm{~mL}$ calibrated flask. The solution was then diluted 5fold to get the working concentration of $200 \mu \mathrm{g} \mathrm{mL}^{-1}$. Hydrochloric acid (5M) was prepared by diluting $43 \mathrm{~mL}$ of concentrated acid (s.d.fine-chem Ltd., Mumbai, Sp gr 1.18) to $100 \mathrm{~mL}$ with water and further appropriately diluted to get $2 \mathrm{M}$ acid. Pharmaceutical grade RLX, certified to be $99.8 \%$ pure was procured from Cipla India Ltd, Mumbai, India, and was used as received. A stock standard solution containing $200 \mu \mathrm{g} \mathrm{mL} \mathrm{m}^{-1} \mathrm{RLX}$ was prepared by dissolving accurately weighed $20 \mathrm{mg}$ of pure drug in $10 \mathrm{~mL}$ glacial acetic acid with aid of heat and diluted to volume with water in a $100 \mathrm{~mL}$ of calibrated flask. The solution was diluted with water to get working concentrations of 5 and $20 \mu \mathrm{g} \mathrm{mL}^{-1} \mathrm{RLX}$ for method A and method B, respectively.

\section{Method using methyl orange (method A)}

Aliquots of pure RLX solution $\left(0.5\right.$ to $\left.4.0 \mathrm{~mL} ; 5 \mu \mathrm{g} \mathrm{mL} \mathrm{m}^{-1}\right)$ were transferred into a series of $10 \mathrm{~mL}$ calibrated flasks and the total volume was adjusted to $4.0 \mathrm{~mL}$ with water. To each flask were added $2 \mathrm{~mL}$ of $5 \mathrm{M}$ hydrochloric acid followed by $1 \mathrm{~mL}$ of bromate-bromide mixture $\left(10 \mu \mathrm{g} \mathrm{mL}^{-1}\right.$ in $\left.\mathrm{KBrO}_{3}\right)$. The content was mixed well and the flasks were set aside for 10 min with occasional shaking. Finally, $1 \mathrm{~mL}$ of $50 \mu \mathrm{g} \mathrm{mL}^{-1}$ methyl orange solution was added to each flask, diluted to the mark with water and the absorbance of solution was measured at $520 \mathrm{~nm}$ against reagent blank after $10 \mathrm{~min}$.

\section{Method using indigo carmine (method B)}

Varying aliquots $(0.5-3.0 \mathrm{~mL})$ of standard $20 \mu \mathrm{g} \mathrm{mL} \mathrm{m}^{-1} \mathrm{RLX}$ solution were measured accurately and delivered into a series of $10 \mathrm{~mL}$ calibrated flasks and the total volume was brought to $3.0 \mathrm{~mL}$ with water. To each flask were added $1 \mathrm{~mL}$ of $2 \mathrm{M}$ hydrochloric acid and $1.5 \mathrm{~mL}$ of bromate-bromide mixture $\left(30 \mu \mathrm{g} \mathrm{mL}^{-1}\right.$ in $\left.\mathrm{KBrO}_{3}\right)$ by means of micro burette; the flasks were let stand for $15 \mathrm{~min}$ with occasional shaking. Then, $1 \mathrm{~mL}$ of $200 \mu \mathrm{g} \mathrm{mL}^{-1}$ indigo carmine solution was added to each flask, the volume was adjusted to the mark with water and mixed well. The absorbance of each solution was measured at $610 \mathrm{~nm}$ against a reagent blank after $10 \mathrm{~min}$.

In either method, the concentration of the unknown was read from the calibration graph or computed from the regression equation derived from the Beer's law data.(Figure 2-3) 




Figure 2. Beer's law curve for method A

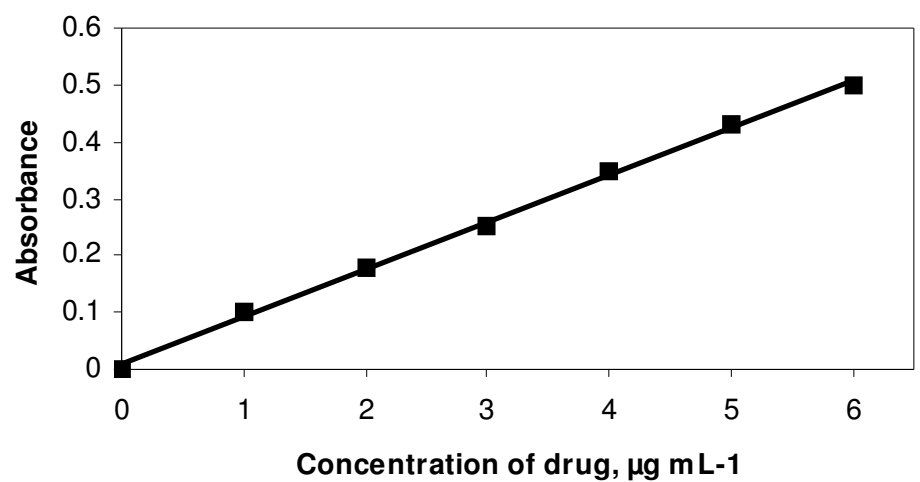

Figure 3. Beer's law curve for method B

\section{Assay procedure for tablets}

An amount of finely ground tablet powder equivalent to $20 \mathrm{mg}$ of RLX was accurately weighed into a beaker, $10 \mathrm{~mL}$ of glacial acetic acid was added and stirred for $20 \mathrm{~min}$, and warmed. Then, the content was transferred to a $100 \mathrm{~mL}$ calibrated flask, the beaker was washed with water and the washings were also transferred to the flask, and the volume was diluted with water to the mark, mixed well, and filtered using a Whatman No 42 filter paper. First $10 \mathrm{~mL}$ portion of the filtrate was discarded and a suitable aliquot of the subsequent portion $\left(200 \mu \mathrm{g} \mathrm{mL} \mathrm{g}^{-1} \mathrm{RLX}\right)$ was diluted appropriately to get 5 and $20 \mu \mathrm{g} \mathrm{mL}$ concentrations for analysis by method A and method B, respectively.

\section{Results and Discussion}

The proposed spectrophotometric methods are indirect and are based on the determination of the residual bromine (insitu generated) after allowing the reaction between RLX and a measured amount of bromine to be complete. The surplus bromine was determined by reacting it with a fixed amount of either methyl orange or indigo carmine dye. The methods make use of bleaching action of bromine on the dyes, the decolouration being caused by the oxidative destruction of the dyes. 
RLX when added in increasing amounts to a fixed amount of insitu generated bromine consumes the latter proportionately and there occurs a concomitant fall in the amount of bromine. When a fixed amount of dye is added to decreasing amounts of bromine, a concomitant increase in the concentration of dye results. Consequently, a proportional increase in the absorbance at the respective $\lambda_{\max }$ is observed with increasing concentration of RLX , as shown by the correlation coefficients of 0.9993 and 0.9989 for method A and method B, respectively.

\section{Method development}

Preliminary experiments were performed to fix the upper limits of the dyes that could be determined spectrophotometrically, and these were found to be 5 and $20 \mu \mathrm{g} \mathrm{mL}^{-1}$ for methyl orange and indigo carmine, respectively. $\mathrm{A} \mathrm{KBrO}_{3}$ concentration of $1.0 \mu \mathrm{g} \mathrm{mL}^{-1}$ in the presence of an excess of bromide was found to irreversibly destroy the red colour of $5 \mu \mathrm{g}$ $\mathrm{mL}^{-1}$ methyl orange whereas $4.5 \mu \mathrm{g} \mathrm{mL}^{-1} \mathrm{KBrO}_{3}$ was required to bleach blue colour due to $20 \mu \mathrm{g} \mathrm{mL} \mathrm{m}^{-1}$ indigo carmine under similar concentration of bromide. Hence, different amounts of RLX were reacted with $1 \mathrm{~mL}$ of $10 \mu \mathrm{g} \mathrm{mL}^{-1} \mathrm{KBrO}_{3}$ in method $\mathrm{A}$ and $1.5 \mathrm{~mL}$ of $30 \mu \mathrm{g} \mathrm{mL}^{-1} \mathrm{KBrO}_{3}$ in method $\mathrm{B}$ followed by determination of the residual bromine as described under the respective procedures.

For both steps, viz, the reaction between insitu bromine and RLX, and bleaching of dye by bromine, hydrochloric acid medium was found to be ideal. Two $\mathrm{mL}$ of $5 \mathrm{M}$ hydrochloric acid and $1 \mathrm{~mL}$ of $2 \mathrm{M}$ hydrochloric acid in a total volume of $\sim 3-4 \mathrm{~mL}$ were adequate for the bromination step in method A and method B, respectively. The reaction was complete in 10 and $15 \mathrm{~min}$ in method $\mathrm{A}$ and method $\mathrm{B}$, respectively, and the same quantity of acid was employed for the estimation of the dye. Contact time of 10 or $15 \mathrm{~min}$ is not critical and any delay up to $30 \mathrm{~min}$ in either method had no effect on the absorbance. The absorbance of the measured colour was constant for several days even in the presence of the reaction product.

\section{Method Validation}

\section{Analytical data}

A linear correlation was found between absorbance at $\lambda_{\max }$ and concentration of RLX.

The graphs showed negligible intercept and are described by the equation:

$$
\mathrm{Y}=\mathrm{a}+\mathrm{bX}
$$

(where $\mathrm{Y}=$ absorbance of $1-\mathrm{cm}$ layer of solution; $\mathrm{a}=$ intercept; $\mathrm{b}=$ slope and $\mathrm{X}=$ concentration in $\mu \mathrm{g} \mathrm{mL}^{-1}$ ). Regression analysis of the Beer's law data using the method of least squares was made to evaluate the slope (b), intercept (a) and correlation coefficient(r) for each system and the values are presented in Table 1. The optical characteristics such as Beer's law limits, molar absorptivity and Sandell sensitivity values of both methods are also given in Table 1. The limits of detection (LOD) and quantitation(LOQ) calculated according to ICH guidelines ${ }^{19}$ are also presented in Table. 1 and reveal the very high sensitivity of the methods.

\section{Accuracy and precision}

To evaluate the accuracy and precision of the methods, pure drug solution at three different levels (within the working limits) was analysed, each determination being repeated seven times. The relative error (\%) and relative standard deviation (\%) were less than 2.0 and indicate the high accuracy and precision for the methods (Table 2). For a better picture of 
reproducibility on a day-to-day basis, a series of experiments were performed in which standard drug solution at three different levels was determined each day for five days with all solutions being prepared afresh each day. The day-to-day relative standard deviation values were in the range of $2.3-3.5 \%$ and represent the best appraisal of the methods in routine use.

Table 1. Analytical and regression parameters of the proposed methods

\begin{tabular}{lcc}
\hline \multicolumn{1}{c}{ Parameter } & Method A & Method B \\
\hline$\lambda_{\max }, \mathrm{nm}$ & 520 & 610 \\
Beer's law limits, $\mu \mathrm{g} \mathrm{mL}^{-1}$ & $0.1-2.0$ & $0.5-6.0$ \\
Molar absorptivity, $\mathrm{mol}^{-1} \mathrm{~cm}^{-1}$ & $1.9 \times 10^{5}$ & $4.5 \times 10^{4}$ \\
Sandell sensitivity, $\mu \mathrm{g} \mathrm{cm}^{-2}$ & 0.003 & 0.011 \\
Limit of detection, $\mu \mathrm{g} \mathrm{mL} \mathrm{mL}^{-1}$ & 0.03 & 0.10 \\
Limit of quantification, $\mu \mathrm{g} \mathrm{mL}^{-1}$ & 0.08 & 0.30 \\
Regression equation, $\mathrm{Y}^{*}$ & & \\
Intercept (a) & 0.0100 & 0.017 \\
Slope (b) & 0.3540 & 0.081 \\
Correlation coefficient, (r) & 0.9993 & 0.9989 \\
$\mathrm{~S}_{\mathrm{a}}$ & 0.011 & 0.008 \\
$\mathrm{~S}_{\mathrm{b}}$ & 0.010 & 0.002 \\
\hline * $\mathrm{Y}=\mathrm{a}+\mathrm{bX}$, where $\mathrm{Y}$ is the absorbance and X concentration in $\mu \mathrm{g} \mathrm{\textrm {mL } ^ { - 1 }}$ \\
$\mathrm{S}_{\mathrm{a}}=$ Standard deviation of intercept. \\
$\mathrm{S}_{\mathrm{b}}=$ Standard deviation of slope.
\end{tabular}

Table 2- Evaluation of accuracy and precision

\begin{tabular}{rrrrrrrrr}
\hline Method & $\begin{array}{r}\text { RLX } \\
\text { taken, } \\
\mu \mathrm{g} \mathrm{mL}^{-1}\end{array}$ & $\begin{array}{r}\text { RLX } \\
\text { Found } \\
\mu \mathrm{g} \mathrm{m}^{-1}\end{array}$ & $\begin{array}{r}\text { Range, } \\
\mu \mathrm{g} \mathrm{mL}^{-1}\end{array}$ & $\begin{array}{r}\text { RE } \\
\%\end{array}$ & $\begin{array}{r}\mathrm{SD}, \\
\mu \mathrm{gL}^{-1}\end{array}$ & $\begin{array}{r}\text { SEM, } \\
\mu \mathrm{g} \mathrm{mL}^{-1}\end{array}$ & $\begin{array}{r}\text { RSD, } \\
\%\end{array}$ & $\begin{array}{r}\text { ROE ** } \\
\%\end{array}$ \\
\hline \multirow{3}{*}{ Method A } & 0.75 & 0.737 & 0.02 & 1.79 & 0.008 & 0.003 & 1.08 & \pm 1.08 \\
& 1.25 & 1.239 & 0.03 & 0.90 & 0.011 & 0.004 & 0.87 & \pm 0.87 \\
& 1.75 & 1.717 & 0.04 & 1.87 & 0.014 & 0.005 & 0.83 & \pm 0.83 \\
Method B & 2.0 & 1.98 & 0.05 & 1.19 & 0.02 & 0.007 & 0.98 & \pm 0.98 \\
& 4.0 & 3.93 & 0.09 & 1.73 & 0.03 & 0.012 & 0.83 & \pm 0.83 \\
& 6.0 & 5.89 & 0.08 & 1.87 & 0.03 & 0.012 & 0.54 & \pm 0.54 \\
\hline
\end{tabular}

RE relative error; SD. Standard deviation; SEM .Standard error of mean; RSD. Relative standard deviation;

ROE.Range of error;

* Mean value of seven determinations

** At the $95 \%$ confidence level for 6 degrees of freedom.

\section{Application to analysis of commercial samples}

In order to check the validity of the proposed methods, RLX was determined in some commercial formulations. Table 3 gives the results of the determination from which it is clear that there is close agreement between the results obtained by the proposed methods and the label claim. The results were also compared statistically by a Student's t- test for accuracy and variance ratio F- test for precision with those of the reference method ${ }^{9}$ at $95 \%$ confidence level. The calculated t- and F-values (Table 3) did not exceed the tabulated 
values $(t=2.77, F=6.39)$, except in a couple of instances, for four degrees of freedom, and indicate that there was no significant difference between the proposed methods and the reference method in respect to accuracy and precision.

Table 3. Results of determination of raloxifene hydrochloride in tablets and statistical comparison with the reference method

\begin{tabular}{|c|c|c|c|c|}
\hline \multirow{2}{*}{$\begin{array}{l}\text { Tablet brand } \\
\text { name }^{\#}\end{array}$} & \multirow{2}{*}{$\begin{array}{l}\text { Nominal } \\
\text { amount, } \\
\text { mg }\end{array}$} & \multicolumn{3}{|c|}{$\%$ Found $* \pm$ SD } \\
\hline & & $\begin{array}{l}\text { Reference } \\
\text { method }\end{array}$ & Method A & Method B \\
\hline FIONA $^{\mathrm{a}}$ & 60 & $100.6 \pm 0.48$ & $\begin{array}{l}99.5 \pm 0.69 \\
t=2.97 \\
F=2.07\end{array}$ & $\begin{array}{l}101 \pm 0.56 \\
t=1.22 \\
F=1.36\end{array}$ \\
\hline GYNISTA $^{\mathrm{b}}$ & 60 & $99.7 \pm 0.56$ & $\begin{array}{l}98.6 \pm 1.01 \\
t=2.21 \\
F=3.25\end{array}$ & $\begin{array}{l}101.6 \pm 1.02 \\
t=3.80 \\
F=3.32\end{array}$ \\
\hline RONAL $^{\mathrm{c}}$ & 60 & $101.6 \pm 0.62$ & $\begin{array}{l}99.8 \pm 1.32 \\
t=2.93 \\
F=4.53\end{array}$ & $\begin{array}{l}101.9 \pm 1.33 \\
t=0.49 \\
F=4.60\end{array}$ \\
\hline
\end{tabular}

* Mean value of five determinations

\#Marketed by: a. Reddy's Ltd. ; b. Micro(Nova) Ltd.; c. Blue cross Ltd.

Tabulated t-value at $95 \%$ confidence level is 2.77

Tabulated F-value at $95 \%$ confidence level is 6.39 .

The accuracy and validity of the proposed methods were further ascertained by performing recovery studies. Pre-analysed tablet powder was spiked with pure RLX at three different levels and the total was found by the proposed methods. Each determination was repeated three times. The recovery of the pure drug added was quantitative and revealed that co-formulated substances such as crospovidone, FD and C Blue No.2 aluminum lake, hypromellose, lactose monohydrate, magnesium stearate, modified pharmaceutical glaze, polyethylene glycol, polysorbate 80 , povidone, propylene glycol, and titanium dioxide did not interfere in the determination. The results of recovery study are compiled in Table- 4 .

Table 4. Results of recovery experiments by standard addition method

\begin{tabular}{|c|c|c|c|c|c|c|c|c|}
\hline \multirow[b]{2}{*}{$\begin{array}{c}\text { Formulation } \\
\text { studied }\end{array}$} & \multicolumn{4}{|c|}{ Method A } & \multicolumn{4}{|c|}{ Method B } \\
\hline & $\begin{array}{c}\text { Amount } \\
\text { of drug } \\
\text { in } \\
\text { tablet, } \\
\mu \mathrm{g}\end{array}$ & $\begin{array}{c}\text { Amount } \\
\text { of pure } \\
\text { drug } \\
\text { added, } \\
\mu \mathrm{g}\end{array}$ & $\begin{array}{c}\text { Total } \\
\text { found } \\
\mu \mathrm{g}\end{array}$ & $\begin{array}{c}\text { Pure drug } \\
\text { recovered* } \\
\%\end{array}$ & $\begin{array}{c}\text { Amount } \\
\text { of drug } \\
\text { in tablet, } \\
\mu \mathrm{g}\end{array}$ & $\begin{array}{c}\text { Amount } \\
\text { of pure } \\
\text { drug } \\
\text { added, } \\
\mu \mathrm{g}\end{array}$ & $\begin{array}{c}\text { Total } \\
\text { found } \\
\mu \mathrm{g}\end{array}$ & $\begin{array}{c}\text { Pure drug } \\
\text { recovered } * \\
\%\end{array}$ \\
\hline \multirow{3}{*}{ FIONA 60} & 4.98 & 2.5 & 7.52 & 101.6 & 20.2 & 10 & 30.56 & 103.6 \\
\hline & 4.98 & 5 & 10.09 & 102.2 & 20.2 & 20 & 40.16 & 99.8 \\
\hline & 4.98 & 10 & 15.00 & 100.2 & 20.2 & 30 & 50.29 & 100.3 \\
\hline \multirow{3}{*}{ RONAL 60} & 5.0 & 2.5 & 7.49 & 99.6 & 20.4 & 10 & 30.61 & 102.1 \\
\hline & 5.0 & 5 & 9.92 & 98.4 & 20.4 & 20 & 40.04 & 98.2 \\
\hline & 5.0 & 10 & 15.13 & 101.3 & 20.4 & 30 & 50.46 & 100.2 \\
\hline
\end{tabular}

*Mean value of three determinations 


\section{Conclusions}

Two useful micro methods for the determination of RLX have been developed and validated. The methods are simple and rapid taking not more than 20-25 min for the assay. Both spectrophotometric methods are more sensitive than the existing UV and HPLC methods, and are free from such experimental variables as heating or extraction step. The methods rely on the use of simple and cheap chemicals and provide sensitivity comparable to that achieved by sophisticated and expensive technique like HPLC. Thus, they can be used as alternatives for rapid and routine determination of bulk sample and tablets as a part of industrial quality control.

\section{References}

1. The Merck Index.12 $2^{\text {th }}$ edn. 1997. pp. 1394.

2. Jin yicui Huaxue Gongye Yu Gongcheng Jishu. 2004, 25, 56.

3. Trontelj Jurij, Vovk Tomaz, Bogataj Marij and Mrhar Ales Pharm. Res. 2005, $\mathbf{5 2 ,} 334$.

4. Wang Qian, Zhang Hongmei and Yu Zhiguo Shenyang Yaoke Daxue Xuebao. 2002,19, 105.

5. Nandini Pai, Jayant and Wagh Padmakar Indian Drugs. 2001, 38, 591.

6. Chen Yanzhong, Lu Zhufen and Zhang Jixing Guangdong Yaoxueyuan Xuebao. 2004, 20, 109.

7. Perez-Ruiz Tomas, Martinez-Lozano Carmen, Sanz Antonio and Bravo Eva $J$. Pharm. Biomed. Anal. 2004, 34, 891.

8. Fan Li, Liu Shao-Pu, Yang Da-Cheng and Hu Xiao-Li Chin. J. Chem. 2002, 20, 1552.

9. Dharuman J, Ravichandran V, Thirumoorthy N and Dharamsi A, Pharmazie. 2004, 59, 720 .

10. Basavaiah K and Prameela H C Science Asia. 2003, 29, 147.

11. Basavaiah K and Prameela H C Anal. Bioanal. Chem. 2003, 376, 879.

12. Basavaiah K and Chandrashekar U Acta. Ciencia. Indica. Chem. 2003, 29, 25.

13. Basavaiah $\mathrm{K}$ and Nagegowda $\mathrm{P}$ ILFarmaco. 2004, 59, 147.

14. Basavaiah K and Nagegowda P Oxid. Commun. 2004, 27, 186.

15. Basavaiah K and Prameela H C Indian J. Pharm. Sci. 2004, 67, 863.

16. Basavaiah K, Indian J. Chem Technol. 2005, 12, 25.

17. Basavaiah K and Nagegowda P J. Braz. Chem. Soc. 2005, 16, 821.

18. Basavaiah K and Somashekar B C Indian. J. Chem. Technol. 2006, 12, 316.

19. Validation of Analytical Procedures; Methodology, International Conference on Harmonization (ICH) 1994,6. 


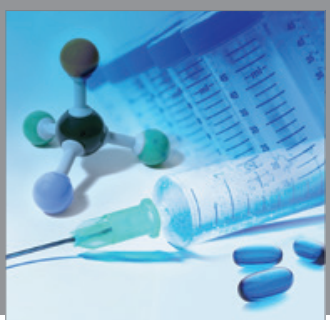

International Journal of

Medicinal Chemistry

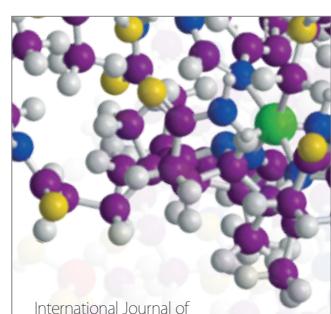

Carbohydrate Chemistry

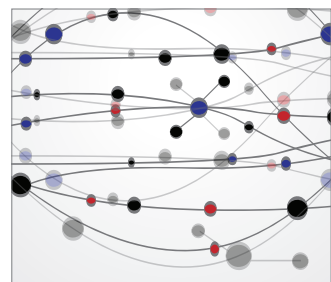

The Scientific World Journal

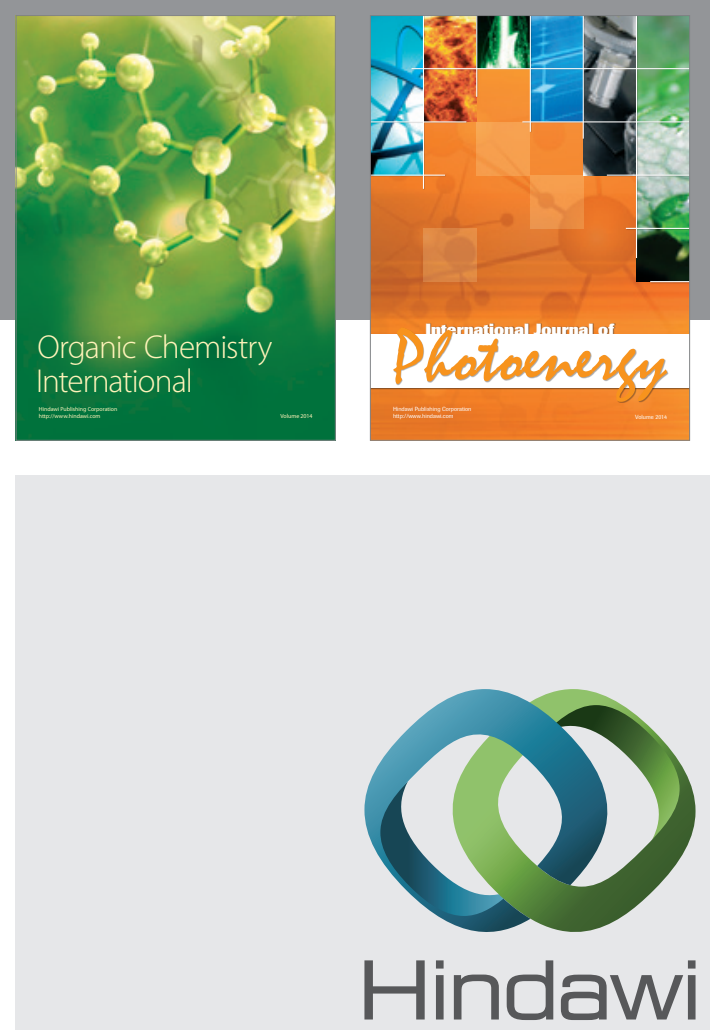

Submit your manuscripts at

http://www.hindawi.com
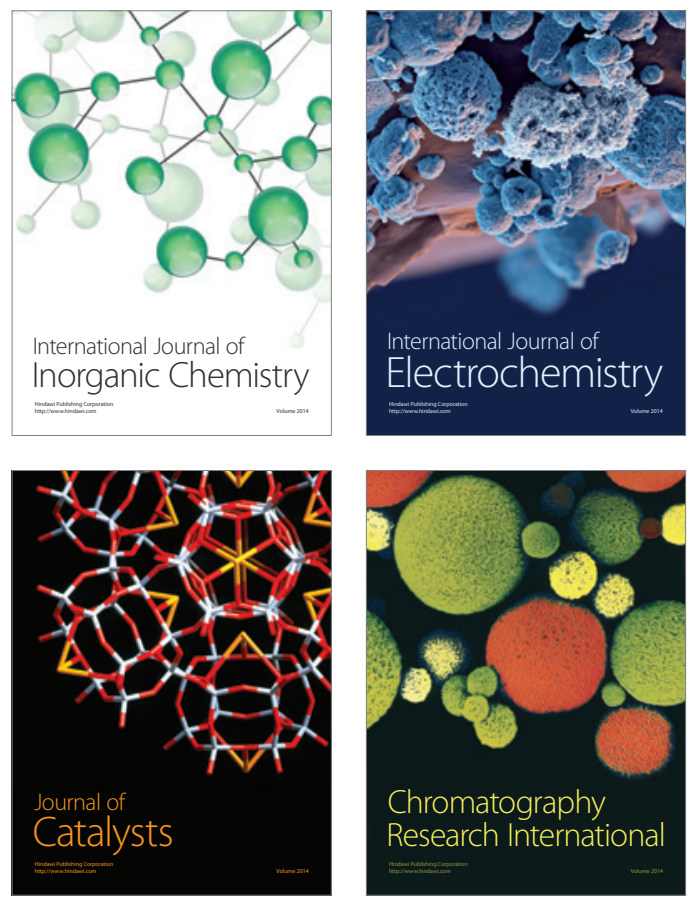
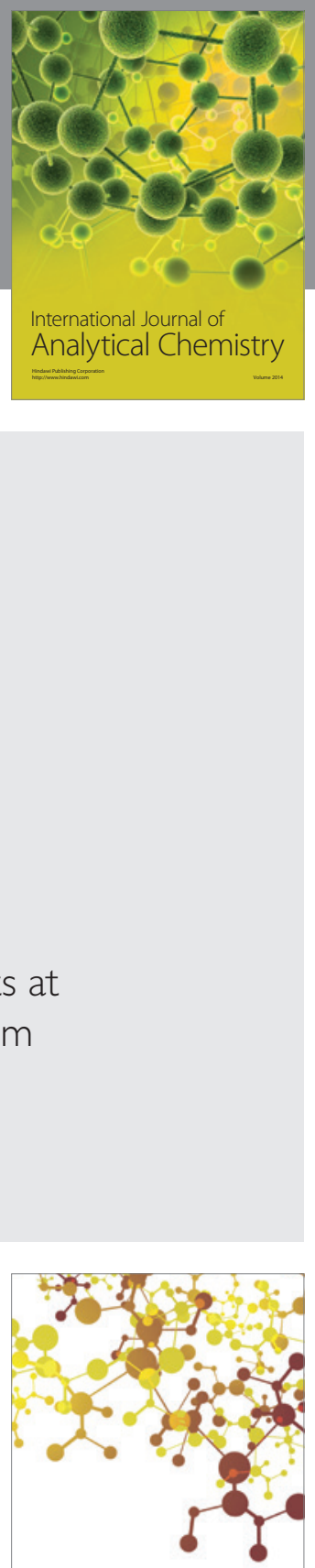

Journal of

Applied Chemistry
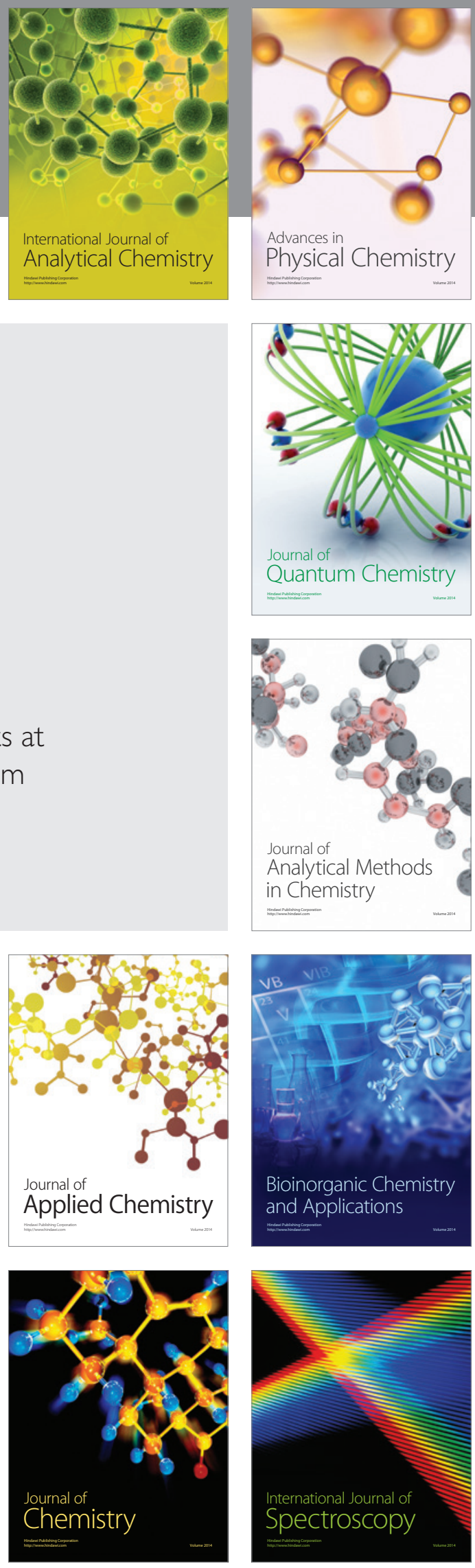